\title{
Serological relationships and purification of bud necrosis virus, a tospovirus occurring in peanut (Arachis hypogaea L.) in India*
}

\author{
By D. V. R. REDDY, A. S. RATNA, M. R. SUDARSHANA **, F. POUL \\ and I. KIRAN KUMAR† \\ Virology Unit, Legumes Program, International Crops Research Institute for \\ the Semi-Arid Tropics (ICRISAT), Patancheru, Andhra Pradesh 502324. \\ India \\ **Division of Plant Pathology, University of Idaho, Moscow, ID 83843, USA
}

(Accepted 8 January 1992)

\begin{abstract}
Summary
A procedure for the purification of a tospovirus which causes bud necrosis disease (BND) of peanut in India is described. The virus contained three polypeptides of $78 \mathrm{kDa}, 54 \mathrm{kDa}$ and $31 \mathrm{kDa}$. In two ELISA procedures the virus failed to react with antisera to tomato spotted wilt virus (TSWV) obtained from different sources and with an antiserum to impatiens necrotic spot virus (INSV). Additionally, in reciprocal tests TSWV and INSV antigens failed to react with antiserum to the virus infecting peanut in India.

In electro-blot immunoassay $54 \mathrm{kDa}$ and $31 \mathrm{kDa}$ polypeptides of the virus reacted with the homologous antiserum. None of the heterologous antisera reacted with any of the three viral polypeptides. On the basis of serological differences the virus that causes BND in India is distinct and therefore has been named bud necrosis virus (BNV). This serotype appears to be restricted to Asia.
\end{abstract}

Key words: Bud necrosis virus, tomato spotted wilt virus, impatiens necrotic spot virus, ELISA, electro-blot immunoassay, serotypes, tospoviruses

\section{Introduction}

The occurrence of bud necrosis disease (BND) on peanut (= groundnut, Arachis hypogaea L.) was first reported from India by Reddy, Reddy \& Rao (1968). It was subsequently shown that BND was caused by a virus which resembled tomato spotted wilt virus (TSWV) (Ghanekar et al., 1979; Reddy et al., 1991). Since the early 1960s BND has been a major constraint to peanut production in several parts of India (Reddy et al., 1991).

Infectivity of BND-infected leaf extracts is dependent upon several factors, the most important of which are the addition of suitable antioxidants to the inoculum and the age of the leaf tissues used. This has hampered earlier attempts to identify the causal virus on the basis of host range and reaction (Reddy, 1988). Also, antisera for TSWV from other countries did not react with the virus obtained from BND-infected plants (Anon., 1989; Sreenivasulu et al., 1991). It was therefore essential to produce antisera against the virus causing BND in India.

Initially, several available methods were tried to prepare virus samples largely devoid of host material. Such preparations are required for production of good quality polyclonal

"Submitted as Journal Article No. 1302 by ICRISAT

†Deceased

(C) 1992 Association of Applied Biologists 
antisera and subsequent development of methods for virus detection and also determination of serological relationships. We report in this paper on purification procedures and the serological relationships of the virus that causes BND of peanut in India

\section{Materials and Methods}

\section{Virus isolate}

Extracts from virus-infected peanut samples, prepared in $0.05 \mathrm{M}$ potassium phosphate buffer, $\mathrm{pH} 7.2$, containing $2 \mathrm{~g}$ /litre thioglycerol were inoculated onto cowpea (Vigna unguiculata, cv. C 152). Virus obtained from a single lesion was reinoculated onto cowpea and after three successive single lesion transfers in cowpea was maintained in peanut (cv. TMV-2) by sap inoculation.

\section{Virus purification}

Systemically infected young quadrifoliates of peanut showing primary symptoms, frozen at $-70^{\circ} \mathrm{C}$, were used. Leaflets were homogenised $(4 \mathrm{ml} / \mathrm{g}$ tissue) in chilled $0.1 \mathrm{M}$ potassium phosphate buffer, pH 7.5, containing $0.01 \mathrm{M}$ sodium sulphite $(0.1 \mathrm{M}$ PPBS). The extract was squeezed through two thicknesses of cheese-cloth and centrifuged at $4000 \mathrm{~g}$ for $10 \mathrm{~min}$. To the supernatant, sodium chloride and polyethyleneglycol (PEG, MW 8000, Fisher Scientific Co.) were added at $11.7 \mathrm{~g} /$ litre and $40 \mathrm{~g} /$ litre respectively, and after dissolving, the mixture was held at $4^{\circ} \mathrm{C}$. After $90 \mathrm{~min}$ to $2 \mathrm{~h}$, the precipitate was collected by centrifuging at $8000 \mathrm{~g}$ for $15 \mathrm{~min}$ and suspended in $0.01 \mathrm{M}$ PPBS $(0.3 \mathrm{ml} / \mathrm{g}$ initial tissue). After centrifugation at $4000 \mathrm{~g}$ for $15 \mathrm{~min}$, the supernatant was layered onto $200-600 \mathrm{~g} /$ litre preformed sucrose gradients (prepared by layering $8 \mathrm{ml}$ of each of 200 and $300 \mathrm{~g} /$ litre, and $12 \mathrm{ml}$ of $600 \mathrm{~g} /$ /itre sucrose in $0.01 \mathrm{M}$ PPBS, and held overnight at $4^{\circ} \mathrm{C}$ ). Gradients were centrifuged at $23000 \mathrm{rpm}$ for $45 \mathrm{~min}$ in a Beckman SW 28 rotor. A diffuse light-scattering zone, at 2.6 to $3.1 \mathrm{~cm}$ from the bottom, was collected. Pellets found in gradient tubers were also suspended in $0.01 \mathrm{M}$ PPBS at a rate of $2 \mathrm{ml}$ for each pellet. Sucrose zones and resuspended pellets were mixed, stirred at $4^{\circ} \mathrm{C}$ for $1 \mathrm{~h}$, layered onto $300-600 \mathrm{~g} /$ litre preformed linear sucrose gradients (prepared by layering $7 \mathrm{ml}$ of each of $300,400,500$ and $600 \mathrm{~g} /$ litre sucrose in $0.01 \mathrm{M}$ PPBS and leaving overnight at $4^{\circ} \mathrm{C}$ ) and centrifuged at $23000 \mathrm{rpm}$ for 2.5 $h$ in the SW 28 rotor. A light-scattering zone between 2.5 to $3.1 \mathrm{~cm}$ from the bottom of the tube was removed, diluted in 0.01 M PPBS, and processed through another cycle of gradient centrifugation as described above. A single light-scattering zone between 2.7 to $3.0 \mathrm{~cm}$ from the bottom of the tube was collected, diluted in $0.01 \mathrm{M}$ PPBS, and the virus was pelleted at $35000 \mathrm{rpm}$ for $2 \mathrm{~h}$ in a Beckman $\mathrm{R} 50$ rotor.

For the removal of proteins, presumed to be of host origin, virus preparations from the 200-600 g/litre sucrose gradients were treated with $5 \mathrm{ml} /$ litre Nonidet P-40 (de Avila et al., 1990 ) in $0.01 \mathrm{M}$ PPBS, gently stirred for $30 \mathrm{~min}$ at $4^{\circ} \mathrm{C}$, and centrifuged ( $\mathrm{R} 50$ rotor; $2 \mathrm{~h}$; $35000 \mathrm{rpm})$.

\section{Antiserum production}

Purified virus (from $100 \mathrm{~g}$ peanut leaves, treated with Nonidet $\mathrm{P} 40$ suspended in $1.0 \mathrm{ml}$ of $0.02 \mathrm{M}$ potassium phosphate buffer, $\mathrm{pH} 7.0$, containing 8.5 g/litre sodium chloride), emulsified with an equal volume of Freunds' incomplete adjuvant, was injected intramuscularly into a New Zealand White inbred rabbit at weekly intervals for 6 wk. The rabbit was bled 10 days after the final injection and thereafter at weekly intervals. 


\section{Heterologous antisera}

The TSWV antisera used in this investigation were generous gifts from $\operatorname{Dr} D$. Peters (TSWV-CNPH1), Dr Mossop (Australia isolate, TSWV-Aus), Dr G. V. Gooding Jr (Greek isolate, TSWV-Grk) and from the American Type Culture Collection (ATCC; TSWV. lettuce or type isolate). Antiserum for impatiens necrotic spot virus (INSV) was a generous gift from AGDIA in a kit form.

\section{Indirect enzyme-linked immunosorbent assay (ELISA)}

Direct antigen coating (DAC) and protein A coating (PAC) ELISA procedures were employed as described by Hobbs, Reddy, Rajeshwari \& Reddy (1987). Protein A (Sigma $\mathrm{P}-8143$ ) prepared in $0.05 \mathrm{~m}$ sodium carbonate buffer, $\mathrm{pH} 9.6$. was used at $1 \mu \mathrm{g} /$ litre. Homologous antiserum was used at 1:2000 dilution for DAC and at 1:1000 dilution for PAC. All heterologous crude antisera were employed at 1:1000 dilution for DAC and at 1:500 dilution for PAC. IgGs from TSWV (CNPH 1) and INSV were used at $2 \mathrm{mg} /$ litre for DAC and PAC procedures. All antisera were cross adsorbed with healthy peanut (cv. TMV-2) leaf extracts (in antigen buffer at $50 \mathrm{~g}$ /litre), for $1 \mathrm{~h}$ at $37^{\circ} \mathrm{C}$. Rabbit Fc-specific IgGs were conjugated to penicillinase (Hindustan Antibiotics Ltd, Pimpri, India) using the glutaraldehyde method described by Sudarshana \& Reddy (1989) and employed at 1:10 (00) and at 1:5000 for DAC and PAC procedures, respectively. Absorbance values were taken at $620 \mathrm{~nm}$ with a Titertek Multiscan MCC ELISA reader.

\section{Polyacrylamide gel electrophoresis of virus proteins}

SDS-protein gel electrophoresis of purified virus preparations was done according to the procedure of Laemmli (1970), as described by Reddy et al. (1990). Only freshly purified virus preparations were used. Proteins from healthy peanut leaves (processed by procedures similar to those used for infected leaves) and from purified TSWV-lettuce isolate (according to the procedure by Sreenivasulu et al., 1991) were included as controls. Gels were stained with silver nitrate as described by Reddy et al. (1990). Phosphorylase B, bovine serum albumin, ovalbumin, carbonic anhydrase and soybean trypsin inhibitor (Bio-rad Laboratories) were used as markers.

\section{Electro-blot immunoassay (EBIA)}

Polypeptides from preparations of purified virus and from healthy leaves were electrophoretically transblotted onto a nitrocellulose paper (Schleicher and Schull BA 83, 0.45 $\mu \mathrm{m}$ pore size) with a semi-dry transfer unit (Reddy et al., 1990) at $15 \mathrm{~V}$ for $1 \mathrm{~h}$. The homologous antiserum was used at a 1:500 dilution. Heterologous antisera were used at 1:250 dilution and IgG for CNPH 1 and INSV were used at $5 \mu \mathrm{g} / \mathrm{ml}$ concentration. Rabbit IgG-specific antibodies prepared in goat (Sigma, USA), conjugated to horseradish peroxidase (Sigma, USA) by the periodate oxidation method (Barbara \& Clark, 1982) were used at a 1:500 dilution. The substrate, 3, 3', 5, 5' -tetramethyl benzidine combined with an enhancer, was obtained from Kirkegaard and Perry Laboratories, USA.

\section{Results}

In the initial experiments, the purification procedure for TSWV reported by Tas, Boerjan \& Peters (1977) was tried. The concentration and the purity of the virus in the final preparations were assessed by ELISA and SDS-protein gel electrophoresis, respectively. ELISA tests were performed in these initial experiments using an antiserum produced 
Table 1: Serological relationship of bud necrosis virus by direct antigen coating (DAC) and protein A coating (PAC) penicillinase based ELISA

\begin{tabular}{|c|c|c|c|c|c|c|c|c|c|}
\hline \multirow[b]{3}{*}{ Antisera } & \multicolumn{9}{|c|}{$\begin{array}{l}\text { Dilution of peanut leaf extracts } \\
\text { (based on original weight of leaf tissue) }\end{array}$} \\
\hline & \multirow{2}{*}{$\begin{array}{l}\text { ELISA } \\
\text { procedure }\end{array}$} & \multicolumn{2}{|c|}{ Healthy } & \multicolumn{2}{|c|}{ BNV } & \multicolumn{2}{|c|}{$\begin{array}{l}\text { TSWV- } \\
\text { Letluce }\end{array}$} & \multicolumn{2}{|c|}{$\begin{array}{l}\text { INSV (from } \\
\text { AGDIA }\end{array}$} \\
\hline & & $10^{-2}$ & $10^{-3}$ & $10^{-2}$ & $10^{-3}$ & $10^{-2}$ & $10^{-3}$ & $10^{-1}$ & $10^{\circ}$ \\
\hline \multirow[t]{2}{*}{ BNV" } & DAC & $0.03 \%$ & 0.02 & 1.59 & 1.22 & 0.10 & 0.12 & $-\cdots$ & - \\
\hline & PAC & 0.09 & 0.06 & 1.15 & 0.82 & 0.15 & 0.04 & 0.04 & 0.0 \\
\hline \multirow{2}{*}{$\begin{array}{l}\text { TSWV-ATCC" } \\
\text { (Lettuce) }\end{array}$} & DAC & 0.04 & 0.04 & 0.15 & 0.13 & 0.74 & 0.44 & - & - \\
\hline & PAC & 0.14 & 0.15 & 0.13 & 0.13 & 0.33 & 0.18 & - & - \\
\hline \multirow{2}{*}{$\begin{array}{l}\text { TSWV-Netherlands }{ }^{+} \\
\text {(CNPH1) }\end{array}$} & DAC & 0.04 & 0.02 & 0.03 & 0.05 & 0.64 & 0.31 & - & - \\
\hline & PAC & 0.09 & 0.05 & 0.06 & 0.04 & 0.25 & 0.06 & - & - \\
\hline \multirow[t]{2}{*}{ TSWV-Australia" " } & DAC. & 0.11 & 0.02 & 0.15 & 0.16 & 1.62 & 0.89 & - & - \\
\hline & PAC & 0.18 & 0.12 & 0.19 & 0.14 & 0.69 & 0.31 & - & - \\
\hline \multirow[t]{2}{*}{ TSWV-Greece" ' } & $\mathrm{DAC}$ & 0.03 & 0.02 & 0.09 & 0.04 & 0.36 & 0.26 & - & - \\
\hline & PAC & 0.09 & 0.08 & 0.10 & 0.12 & 0.27 & 0.18 & - & - \\
\hline INSV+ & PAC & 0.06 & 0.06 & 0.07 & 0.06 & 0.08 & 0.05 & 0.92 & 0 \\
\hline
\end{tabular}

-Cross-adsorbed with healthy peanut leaf extracts. Source of each antiserum given in the text.

*The mean A $620 \mathrm{~nm}$ value for three replicates, after subtracting from values for buffer controls.

-*Test not done.

- Used at 1:2000 dilution for DAC and at 1:1000) dilution for PAC.

+Supplied as IgG. used at $2 \mathrm{mg} /$ litre.

${ }^{+}$Used at 1:1000 dilution for DAC and at 1:500 dilution for PAC.

against virus prepared by the procedure described by Mohamed, Randles \& Francki (1973). Though the serum gave high titre with healthy plant extracts, it was possible to use it in comparative tests to estimate the concentration of viral antigens. The recovery of viral antigen, as determined in three experiments, was $18 \%$ of that present in crude plant extracts as opposed to $30 \%$ by the method described in this paper. Purified virus, obtained by the procedure described, retained approximately $9 \%$ of infectivity of that present in crude plant extracts.

In DAC- and PAC-ELISA procedures the virus from BND-infected plants reacted strongly with the homologous antiserum. Antisera for various TSWV isolates and for INSV (Law \& Moyer, 1990) failed to detect the virus (Table 1).

Fig. 1. SDS polyacrylamide slab gel showing three polypeptides from purified bud necrosis virus (BNV) and many polypeptides from healthy peanut leaves, processed by a procedure similar to that for infected peanut leaves. $a$. Purified BNV + polypeptide from healthy peanut leaves. $b$. Polypeptides from healthy peanut leaves. $c$. Purified BNV.

Fig. 2. SDS polyacrylamide slab gel showing purified BNV, untreated and treated with Nonidet P-40 (at $5 \mathrm{~g}$ /litre, stirred for $30 \mathrm{~min}$ and pelleted at high speed). a. BNV treated with Nonidet P.40. b. Same as (a) but loaded at $1 / 10$ th concentration to show migration rate of nucleocapsid protein. $c$. Molecular weight markers. $d$. BNV untreated.

Fig. 3. SDS polyacrylamide slab gel showing polypeptides of tomato spotted wilt virus (TSWV) and BNV. a. BNV. b. BNV + TSWV. c. TSWV.

Fig. 4. Electroimmunoblot of BNV and TSWV proteins after probing with homologous and heterologous antisera: a) BNV polypeptides probed with homologous antiserum, b) BNV polypeptides probed with TSWV (ATCC) antiserum, c) BNV polypeptides probed with INSV antiserum, d) BNV polypeptides probed with TSWV (CNPH1) antiserum, e) Polypeptides from healthy peanut leaves probed with BNV antiserum, f) TSWV polypeptides probed with TSWV (ATCC) antiserum, 8) TSWV polypeptides probed with TSWV (CNPHI) antiserum, h) TSWV polypeptides probed with BNV antiserum. 
The virus contained three structural proteins of molecular weight $78 \mathrm{kDa}(\mathrm{Gl}), 54 \mathrm{kDa}$ (G2) and $31 \mathrm{kDa}(\mathrm{N})$ (Figs 1 and 2). Minor polypeptides observed in some preparations could be removed by treatment with Nonidet P-4) (Fig. 2). G1 and G2 polypeptides of TSWV-lettuce isolate from peanut comigrated with those of the virus. Differences in the apparent molecular weight of the $\mathrm{N}$ proteins between the virus ciasing BND and TSWVlettuce could be resolved (Fig. 3).

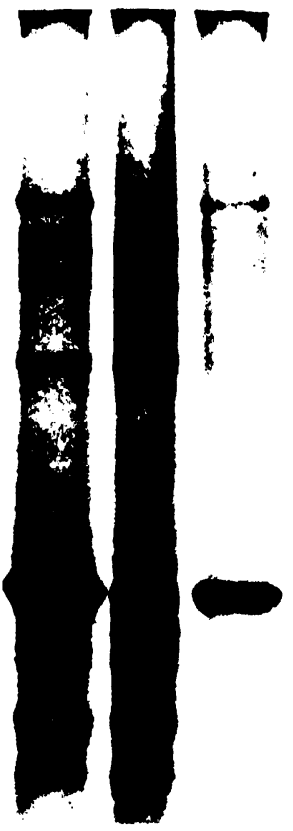

Fig. 1

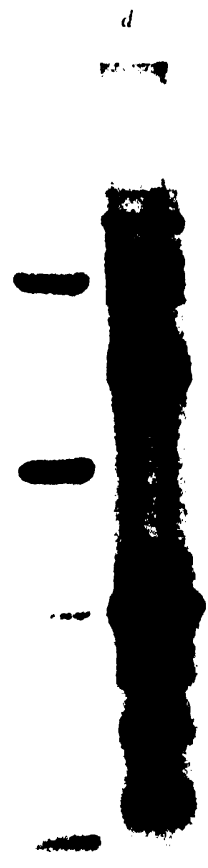

Fig. 2

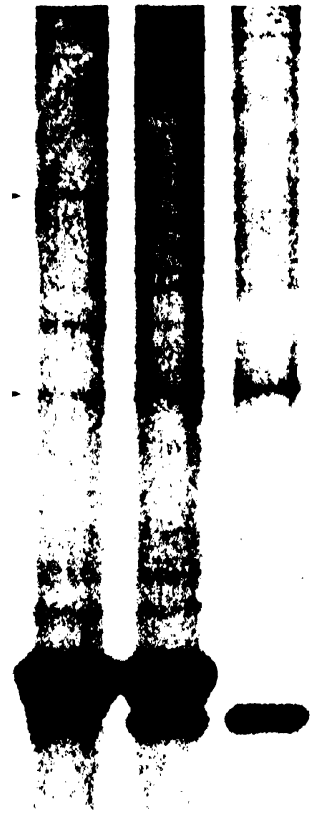

Fig. 3

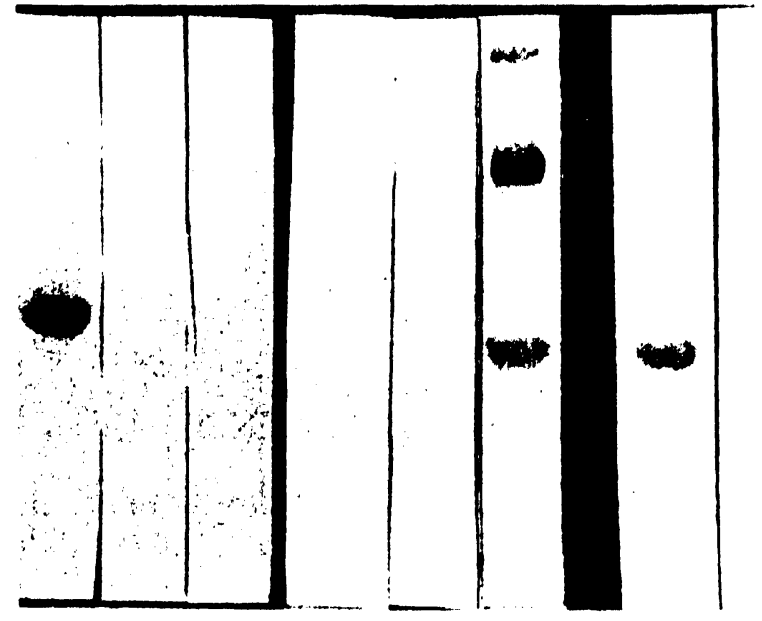

Fig. 4 
Although antibodies to the virus were produced from preparations containing all the three polypeptides (Fig. 2) in EBIA, the $78 \mathrm{kDa}(\mathrm{Gl}$ ) could not be detected (Fig. 4). Either the serum did not contain antibodies to $G 1$ or those produced did not react with the denatured polypeptide. The serum did not react with any of the polypeptides of TSWVlettuce isolate from peanut. In reciprocal tests all the three proteins of TSWV-lettuce from peanut were detected by the TSWV antiserum from ATCC and a serum from the Netherlands produced for nucleocapsids (CNPH 1) reacted only with the $\mathrm{N}$ protein (Fig. 4). TSWV-Aus and TSWV-Grk antisera did not react with any of our virus polypeptides although they reacted with all the three polypeptides of TSWV-lettuce (data not shown). Also, INSV (tested only with our isolate) failed to react with all the polypeptides of our virus (Fig. 4).

\section{Discussion}

The purification procedure developed for the virus that causes BND was also used to purify TSWV (Sreenivasulu et al., 1991) from peanut. Treatment with Nonidet P.40 was essential to obtain preparations devoid of minor polypeptides, presumably of host origin. whose presence and concentration varied from sample to sample.

Several reports have recently been published on the serological relationships of TSWV as determined by utilising polyclonal and monoclonal antibodies. TSWV-lettuce (or type) isolate and INSV were placed under serogroups I and II, respectively. Various forms of ELISA tests have been employed to distinguish isolates within serogroups (de Avila et al.. 1990; Wang \& Gonsalves, 1990). de Avila et al. (1990) have investigated 20 isolates, which could be classified in serogroup 1 , but two types could be distinguished within this serogroup on the basis of reaction with the N protein. INSV (Law, Speck \& Moyer, 1991) which was initially referred to as TSWV-Impatiens (Law \& Moyer, 1990) had N protein which was serologically unrelated to that of TSWV-lettuce. However, the molecular weight of the $N$ protein of INSV was identical to that of the N protein of TSWV. G1 and G2 proteins of INSV and TSWV were serologically related and had similar molecular weights.

Results clearly show that the tospovirus which causes BND in India is serologically distinct from TSWV and INSV. In this study two different forms of ELISA produced very similar results. In EBIA, all three polypeptides of the virus did not react with several antisera to TSWV and with one antiserum to INSV. Interestingly, the virus contained $31 \mathrm{kDa} \mathrm{N}$ protein, similar to a tospovirus occurring in Japan on watermelon (Kameya-Iwaki, Hanada, Honda \& Tochihara, 1988) and peanut yellow spot virus (PYSV) occurring in India and Thailand (Reddy et al., 1990). In reciprocal tests PYSV and the virus causing BND were serologically unrelated. Additionally both the viruses differed in host range (Reddy et al., 1990).

Tospoviruses, to which TSWV belongs, are considered to be similar to animal viruses in the Bunyaviridae group (Milne \& Francki, 1984; de Haan, Wagemakers, Goldbach \& Peters, 1989). Serological relationships among the structural proteins have been used for classifying individual members within the genera of Bunyaviridae. It is apparent from the data obtained so far that members of tospoviruses could be distinguished on the basis of serological differences in $\mathrm{N}$ protein, indicating that the $\mathrm{N}$ protein is not conserved in the different serogroups. We propose that the virus causing BND should be called bud necrosis virus (BNV), and that it be placed in a different serogroup, preferably serogroup III. None of the isolates of TSWV and INSV investigated so far has been derived from Asia. BNV antiserum reacted, in electro-immuno blots, with the tospovirus isolated from watermelon in Japan, which causes silver mottle disease (G. Adam, personal communication) and 
antiserum for the tospovirus from watermelon also reacted with BNV in both DAC and PAC-ELISA tests (D. V. R. Reddy, unpublished). Therefore the tospovirus from watermelon is serologically related to BNV. Additionally, BNV and the tospovirus from watermelon could be transmitted by Thrips palmi (M. Kanncyal-Iwaki, personal com. munication; K. Vijayalakshmi, D. V. R. Reddy, A. S. Reddy, G. V. Ranga Rao, J. A. Wightman and D. D. R. Reddy, unpublished). Interestingly, the TSWV-lettuce isolate could not be transmitted by $T$. palmi (Mau et al., 1990). From DAC and PAC-ELISA tests on $15 \mathrm{BNV}$ isolates occurring on peanut in different parts of India, it was apparent that all the isolates reacted with BNV antiserum and none reacted with TSWV-lettuce or INSV antisera. Antiserum for BNV also reacted with various isolates of a tospovirus collected in China (D. V. R. Reddy \& Xu Zeyong, unpublished). Nevertheless additional data are required to determine if the viruses in serogroup III are wholly or predominantly Asian. We also propose that PYSV should be included in serogroup IV. Though the thrips vectors of serogroups I and II appear to be similar, serogroups III and IV are transmitted by different thrips vectors. Experiments on transmission of different serogroups by different thrips species may provide additional data to distinguish different serogroups.

TSWV occurs on peanut throughout the world (Reddy et al., 1991), but serological relationships of various TSWV isolates have only recently been investigated. Serological diversity among the tospoviruses occurring in peanut has recently been reported. An isolate from South Africa, though regarded as a distinct serotype, reacted with antisera to TSWV. lettuce under serogroup I (de Avila et al., 1990; Adam, Lesemann \& Vetten, 1991). None of the isolates collected in the USA reacted with BNV which was referred to as TSWV. Indian (Sreenivasulu et al., 1991). It is currently not known if INSV can infect peanut under field conditions. Probably at least three serogroups occur in peanut and therefore surveys for tospoviruses in peanut should include tests with several antisera.

\section{Acknowledgements}

We are grateful to Dr D. McDonald for his many valuable comments on the manuscript and to DrG. Adam for the supply of antiserum to the tospovirus isolated from watermelon.

\section{References}

Adam, G., Lesemann, D. E. \& Vetten, H. J. (1991). Monoclonal antibodies against tomato spotted wilt virus: Characterisation and application. Annals of Applied Biology 118, 87-104.

Anon. (1989). Annual Report, p. 163. Patancheru, India: International Crops Research Institute for the Semi-Arid Tropics.

Barbara, D. J. \& Clark, M. F. (1982). A simple indirect ELISA using $F(a b)_{2}$ fragments of immunoglobulin. Journal of General Virology 58, 315-322.

de Avila, A. C., Huguenot, C., Resende, R. de. O., Kitajima, E. W., Goldbach, R. W. \& Peters, D. (1990). Serological differentiation of 20 isolates of tomato spotted wilt virus. Journal of General Virology 71, 2801-2807.

de Haan, P., Wagemakers, L., Goldbach, R. \& Peters, D. (1989). Tomato spotted wilt virus, a new member of the Bunyaviridae? In Genetics and Pathogenicity of Negative Strand Viruses, pp. 287291. Eds D. Kolakofsky and B. W. J. Mahy. Amsterdam: Elsevier.

Ghanekar, A. M., Reddy, D. V. R., lizuka, N., Amin, P. W. \& Gibbons, R. W. (1979). Bud necrosis disease of groundnut (Arachis hypogaea) in India caused by tomato spotted wilt virus. Annals of Applied Biology 93, 173-179.

Hobbs, H. A., Reddy, D. V. R., Rajeshwari, R. \& Reddy, A. S. (1987). Use of direct antigen coating and protein A coating ELISA procedures for detection of three peanut viruses. Plant Disease 71, 747-749. 
Kameya-Iwaki, M., Hanada, K., Honda, Y. \& Tochihara, H. (1988). A watermelon strain of tomato spotted wilt virus (TSWV.W) and some properties of its nucleocapsid. Fifth International Congress of Plant Pathology, p. 64 (Abstract).

Laemmli, U. K. (1970). Cleavage of structural proteins during the assembly of the head of bacteriophage T4. Nature 227, 680-685.

Law, M. D. \& Moyer, J. W. (1990). A tomato spotted wilt-like virus with a serologically distinct N protein. Journal of General Virology 71, 933-938.

Law, M. D., Speck, J. \& Moyer, J. W. (1991). Differences in the N protein nucleotide sequence between tospovirus serogroups. Phytopathology (Abstract).

Mau, R. F. L., Bautista, R., Cho, J. J., Ullman, D. E., Gusukuma-Minuto, L. \& Custer, D. (1990). Factors affecting the epidemiology of TSWV in field crops. Comparative virus acquisition efficiency of vectors and suitability of alternate host to Frankliniella occidentalis (pergande). In Proceedings of Tomato Spotted Wilt Virus Workshop (1990), pp. 21-27. Beltsville, Maryland, USA: USDA.

Milne, R. G. \& Francki, R. I. B. (1984). Should tomato spotted wilt virus be considered as a possible member of the family Bunyaviridae? Intervirology 22, 72-76.

Mohamed, N. A., Randles, J. W. \& Francki, R. I. B. (1973). Protein composition of tomato spotted wilt virus. Virology $56,12 \cdots 21$.

Reddy, D. V. R. (1988). Groundnut virus diseases occurring in India. In Monograph of groundnut, pp. 508-525. Ed. P. S. Reddy. New Delhi, India: Indian Council of Agricultural Research.

Reddy, M., Reddy, D. V. R. \& Appa Rao, A. (1968). A new record of virus disease on peanut. Plant Disease Reporter 52, 494-495.

Reddy, D. V. R., Sudarshana, M. R., Ratna, A. S., Reddy, A. S., Kiran Kumar, I. \& Murthy, A. K. (1990). The occurrence of yellow spot virus, a new member of tomato spotted wilt virus group, on peanut (Arachis hypogaea L.) in India. In Proceedings of Tomato Spotted Wilt Virus Workshop, (1990), pp. 77-83. Beltsville, Maryland, USA: USDA.

Reddy, D. V. R., Wightman, J. A., Beshear, R. J., Highland, B., Black, M., Sreenivasulu, P., Dwivedi, S. L., Demski, J. W., McDonald, D., Smith, J. W. \& Smith, D. H. (1991). Bud Necrosis - a disease of groundnut caused by tomato spotted wilt virus, p. 20. ICRISAT Information Bulletin, International Crops Research Institute for the Semi-Arid Tropics, ICRISAT, Patancheru, Andhra Pradesh 502 324, India.

Sreenivasulu, P., Demski, J. W., Reddy, D. V. R., Naidu, R. A. \& Ratna, A. S. (1991). Purification and some serological relationships of tomato spotted wilt virus isolates occurring on peanut (Arachis hypogaea) in the USA. Plant Pathology 40(4), 503-507.

Sudarshana, M. R. \& Reddy, D. V. R. (1989). Penicillinase-based enzyme linked immunosorbent assay for the detection of plant viruses. Journal of Virological Methods 26, 45-52.

Tas, P. W. L., Boerjan, M. L. \& Peters, D. (1977). Purification and serological analysis of tomato spotted wilt virus. Netherlands Journal of Plant Pathology 83, 61-72.

Wang, M. \& Gonsalves, D. (1990). ELISA detection of various tomato spotted wilt virus isolates using specific antisera to structural proteins of the virus. Plant Disease 74, 154-158.

(Received 9 October 1991) 